\title{
Special Issue on Politics and Literature: Introductory Note by the Editor
}

This issue of The Review of Politics is dedicated to the memory of Wilson Carey McWilliams, a long-time member of our Advisory Board and enthusiastic supporter of the study of politics through literature. He was one of the founding members of the organized section on "Politics and Literature" established by the American Political Science Association in 1993. His essay on "Divine Right: Mark Twain's Joan of Arc" is posthumously published here for the first time with the permission of his literary executor, Nancy McWilliams.

With the exception of McWilliams's piece on Mark Twain's Joan of Arc, all the articles in this issue were submitted to The Review of Politics during the last two years and subjected to the regular blind peer review process. As a result, the volume does not have a preset organization or agenda-beyond a demonstration of the kind of exciting work and deep insights to be gained from political analyses of literary works. The articles address a variety of issues, raised by literary works of different genres, at different times and places. We make no claim to offer a typical, much less exhaustive, sample of the kind of work that can be done in this newly emerging area of political science. There is no essay on Greek tragedy, for example, nor is there an analysis of a contemporary film.

That said, the articles can be seen to divide or cluster into three sets, separated from each other by the dominant questions raised, times, and conditions under which the literary works were produced. In the first two articles, Wilson Carey McWilliams and Carson Holloway examine literary presentations and critiques of traditional forms of political heroism. In the second two articles, Paul Cantor and Jason Frank show the way in which romantic poets attempted to redefine the relation between poetry and politics in the age of modern democracy. And in the third set of articles, Sanford Kessler and Michael Keren bring out the critiques of modern democratic practice and theory to be found in the novels of two twentieth century Nobel Prize winners.

In his study of "Shakespeare's Coriolanus and Aristotle's Great-Souled Man," Holloway argues that Coriolanus's "intolerance of insult" is not a reflection of a merely personal preoccupation with his own status, but expresses his moral seriousness. Like Aristotle's magnanimous man, Coriolanus knows what he and his service to the city are worth; he does not need or depend on the recognition of others, although he thinks he deserves it. Nevertheless, Holloway concludes, Shakespeare's Coriolanus falls short of the magnanimous man in his lack of prudence and his unphilosophic understanding of virtue solely in terms of the Roman republic. 
Looking back at the phenomenon of the founder-general from a more modern, democratic perspective, in Joan of Arc Twain emphasizes the untraditional characteristics of his heroine-the fact that she was not only a woman but also a plebeian. Neither Twain nor his purported source of information, Sieur Louis de Conte, fully accept Joan's claims about the religious sources of her decisions. They present her simply as someone who believes in her "voices" and describe the limits of her charismatic leadership. As an admirer of the French as well as the American Revolution, Twain thought that the order Joan founded proved to be terribly unjust. Although Twain's depiction of Joan acknowledges the true excellence of a famous aristocratic individual, McWilliams argues his novel is designed to counteract the worshipful emulation of past aristocracies in nineteenth-century America that threatened to undermine the democratic regime.

In "The Politics of the Epic: Wordsworth, Byron, and the Romantic Redefinition of Heroism," Paul Cantor describes the quandary in which the romantic poets found themselves. In modern, increasingly democratic political circumstances, they did not think they could celebrate the deeds or demise of great individuals the way earlier epic and tragic poets had. The romantic poets solved the problem by making the poet and his consciousness the center of their poems.

Walt Whitman was attracted by the heroic vision of the poet, Jason Frank argues, but he ultimately resisted this unitary, undemocratic vision of the poet as author and authority. In attempting to give expression to the ever newly creative polyphonous voice of the people, Whitman was trying to establish an aesthetic form of democracy.

Neither of the twentieth-century novels treated in the last two essays presents as promising a view of the moral, political, or aesthetic possibilities of modern democracy. In Shadows on the Hudson, Sanford Kessler argues, Isaac Bashevis Singer despairs both about the moral emptiness of secular American life and about the possibility of a return to orthodox religion. Michael Keren uses José Saramago's novel Blindness to provide a richer understanding of the behavioral assumptions underlying contemporary democratic theory. Rational choice is not enough. Once a realistic element of evil is introduced into the bargaining process, the novel shows, such bargaining has little chance of resulting in a decent social order.

The essays included in this issue could have been grouped on the basis of different principles. Most critics would treat Whitman and Twain together as nineteenth century American authors. Frank and Keren both explicitly address questions of democratic theory. McWilliams and Kessler both investigate the role of religion in politics.

We publish these articles in the hope that they will inspire other, equally provocative and insightful inquiries into the many ways literary studies can enhance and enrich political theory. If so, both the spirit and the work of Carey McWilliams will live on. 